of the Commission wished to abolish the sixpenny doctor altogether. "But we have not come to the decision that all sixpenny doctors are bad," said Dr. Greenwood. It was how the doctor did his work, and one man for sixpence would do as good work as another man would do for a larger fee. Urgent cases were attended to, but nobody knew how far they really were urgent. There should be in every service loopholes by which those cases were attended to. But if they were taking the essentials of life it was no more necessary for a man to get medical attendance free than for him to receive food free. Unless they could show that medical attendance on the one hand was much more important he could not see the reason why one form of relief should be taken out of the relieving officers' hands and not another. Referring to the question of "plums," Dr. Green. wood said he was led into that by Mrs. Sidney Webb. As to co-operation and co-ordination with other services, that might be done to any extent.

The Chairman thanked Dr. Greenwood for his interesting paper and the meeting then closed.

\section{THE TERRITORIAL ARMY AND ITS SANITARY CORPS.*}

By HERBERT PECK, M.D., D.P.H.,

Captain in the Sanitary Corps of the Royal Army Medical Corps, Territorial Force; Medical Officer of Health for the Borough and Rural District of Chesterfield.

THE Territorial Force is now an Army in being, and it appears desirable that the arrangements made for the sanitary work in connection with it should be carefully considered with a view to their being made as efficient as possible.

Although it is needless to dwell upon the necessity of such a corps as Mr. Haldane has initiated, a short review of the mortality in some recent campaigns will show how necessary it is.

The admission to hospital for sickness and wounds and deaths from wounds, or being killed in action, in British wars since 1873 , are shown in the table on next page.

These figures, for which I am indebted to Lieutenant-Colonel Firth's valuable book, "Military Hygiene," show that in the campaigns of the last fifteen years the admissions to hospital on account of sickness averaged about thirty-six times those from wounds, and the deaths $37^{\circ} 6$ times as many. Lieutenant-Colonel Firth gives the averages, taken over a longer

* Presidential Address to the North-Western Branch of the Society of Medical Officers of Health, delivered October 15th, $190 \mathrm{co}$ period, as twenty-five men admitted for sickness for one admitted for wounds, and the deaths from sickness as five to one from wounds.

In the twenty-one months of the RussoJapanese War, the Japanese had one admission for wounds for I'I 5 admissions from sickness, and one death from wounds or being killed in action for $0^{3} 37$ of a death from sickness. These are the figures given in an editorial of the British Medical Journal, the translation of an address given at Tokio, by Surgeon-LieutenantGeneral M. Koike, in The Royal Army Medical Corps Journal for December, rgo6, La Semaine Médicale, No. 29, I906, and the Russki-Invalid, November and December, Igo6.

The editor of the Royal Army Medical Corps Journal, in a review of Surgeon-General Koike's address, warns those comparing the figures given in it with those of other wars that the very large increase in the number of wounded and killed must influence the proportion just as much as a decrease in the number suffering or dying from disease, and says "the closer one examines the figures, the more one is forced to the conclusion that the former and not the latter condition has been the chief influence at work in determining the marked alteration in the proportion of deaths from disease to deaths from wounds, in the Russo-Japanese War, as compared with the immediately preceding wars."

It must be remembered against this view. that the amount of sickness in both armies, as will be seen later, is stated to have been less than in time of peace.

The Russki-Invalid makes the following comparison :-

$\begin{array}{lrrr} & \begin{array}{c}\text { Russian } \\ \text { Army. }\end{array} & \text { Japanese } \\ & \text { Army. } \\ \text { Admissions for disease ... } & \ldots & 333,411 & 334,073 \\ \text { Proportion per 1, } 000 \text { of strength } & 24425 & \mathbf{2 2 0 . 5 1}\end{array}$

The rates are based on the estimate that the average strength of the Russian Army was $r, 365,000$, and that of the Japanese Army I,515,000. The writer attributes the higher disease rate among the Russian troops to the fact that the climate and country of Manchuria were more strange to them than to the Japanese.

The same writer gives the Russian deaths from wounds, including killed in action, as I to 0.27 from disease. You will remember the Japanese rate from disease was $0^{\circ}$ ro higher.

No absolute reliance can be placed on the figures of the Russki-Invalid with regard to sickness, for the editor of the British Medical Journal and Surgeon-Lieutenant-General Koike 


\begin{tabular}{|c|c|c|c|c|c|c|c|c|c|c|}
\hline \multirow{2}{*}{\multicolumn{5}{|c|}{ EXPEDITION OR WAR. }} & \multicolumn{6}{|c|}{ RATIOS PER $x, 000$ OF STRENGTH. } \\
\hline & & & & & \multirow[b]{2}{*}{$\begin{array}{l}\text { For } \\
\text { Disease. }\end{array}$} & \multicolumn{2}{|c|}{ ADMISSIONS. } & \multicolumn{3}{|c|}{ DEATHS. } \\
\hline & & & & & & $\begin{array}{l}\text { for } \\
\text { Wounds } \\
\text { or } \\
\text { Injuries } \\
\text { in } \\
\text { Action. }\end{array}$ & Total. & $\begin{array}{c}\text { From } \\
\text { Disease. }\end{array}$ & $\begin{array}{c}\text { From } \\
\text { Wounds } \\
\text { or } \\
\text { Killed } \\
\text { in } \\
\text { Action. }\end{array}$ & Total. \\
\hline Ashanti, $1873-1874$ & $\ldots$ & $\cdots$ & $\ldots$ & $\ldots$ & $474^{\circ} \circ$ & 70.0 & $544^{\circ} \circ$ & $160^{\circ}$ & 60 & 220 \\
\hline Perak, $1875-1876$ & $\ldots$ & $\ldots$ & $\ldots$ & .. & $227^{\circ} 0$ & $1 \cdot 6$ & 2286 & $20^{\circ} 0$ & 16 & 21.6 \\
\hline Zululand, $1879-1880$ & $\ldots$ & $\ldots$ & $\ldots$ & $\ldots$ & $739^{\circ}$ & 120 & $751 \%$ & $24^{8} 83$ & $1 \cdot 8$ & 26.63 \\
\hline Afghanistan, $1879-1880$ & & $\ldots$ & $\ldots$ & $\ldots$ & 8699 & $51 \%$ & 9209 & 36.03 & 6.92 & $42 \cdot 95$ \\
\hline Egypt, $1882 \quad \ldots$ & $\cdots$ & $\ldots$ & $\ldots$ & $\ldots$ & $554 \circ$ & 290 & $583^{\circ} \circ$ & 606 & $7 \cdot 15$ & 1321 \\
\hline Sudan, $1884 \quad \ldots$ & $\ldots$ & $\ldots$ & $\ldots$ & ... & $76 \cdot 2$ & 492 & 1254 & - & $3 r \cdot 36$ & $31 \cdot 36$ \\
\hline Nile, $1884-1885 \ldots$ & $\cdots$ & ... & $\ldots$ & $\ldots$ & $808 \cdot 6$ & 224 & 8310 & $40^{\circ} 01$ & 1170 & 5171 \\
\hline Suakim, I $885 \quad \ldots$ & $\cdots$ & $\ldots$ & $\ldots$ &. & 2829 & 137 & $296 \cdot 6$ & 7.87 & 6.50 & 1437 \\
\hline Sudan, $1885-1886$ & ... & $\ldots$ & $\ldots$ & .. & $1100 * 3$ & 46.9 & $1147 \% 2$ & 2944 & 982 & 39.26 \\
\hline Nile, $1889 \ldots$ & ... & $\ldots$ & $\ldots$ & $\ldots$ & $73 \cdot 5$ & $3 \cdot 3$ & 768 & I'3I & 0.65 & 196 \\
\hline Ashanti, $1895-1896$ & ... & $\ldots$ & $\ldots$ & $\ldots$ & 49.27 & - & $49 \cdot 27$ & 0.56 & - & 0.56 \\
\hline Chitral, I $895 \quad \ldots$ & $\ldots$ & $\ldots$ & $\ldots$ & ... & $1530^{\circ} 0^{\circ}$ & 140 & $1544^{\circ} 0$ & $49 * 39$ & 510 & 54.49 \\
\hline Dongola, $1896 \quad \ldots$ & $\ldots$ & $\ldots$ & $\ldots$ & ... & 9766 & - & 9766 & 8170 & - & 817 \\
\hline Bechuanaland, 1896 & ... & $\ldots$ & $\ldots$ & $\ldots$ & 5310 & 110 & $542 \circ$ & 28.60 & 26 & 312 \\
\hline Mashonaland, 1896 & $\cdots$ & $\ldots$ & $\ldots$ & $\ldots$ & 7820 & $53^{\circ} \mathrm{O}$ & $835 \circ$ & 380 & $15^{\circ} \circ$ & I 8.8 \\
\hline Tirah, $1897-$ I 898 & $\ldots$ & $\ldots$ & $\cdots$ & $\cdots$ & 5738 & $25^{\circ} 6$ & $599^{\circ} 4$ & $28 \cdot 24$ & 267 & 30.91 \\
\hline Nile, $1898 \ldots \quad \ldots$ & $\ldots$ & $\ldots$ & $\ldots$ & $\ldots$ & 11017 & 56.7 & $1058 \cdot 4$ & $36 \cdot 18$ & 15.67 & 5185 \\
\hline China, 1900-1901 & $\ldots$ & $\ldots$ & $\ldots$ & $\ldots$ & 10517 & 102 & 1061.9 & $22 \cdot 71$ & $2 \cdot 35$ & 25.06 \\
\hline South Africa, $1899-190$ & & $\cdots$ & $\ldots$ & $\ldots$ & 7460 & $34^{\circ}$ & $780^{\circ} 0$ & $69^{\circ} 0$ & $42 * 0$ & IIJ*6 6 \\
\hline
\end{tabular}

give 236,223 as the total number of Japanese sick. There is also a discrepancy between the last two authorities, inasmuch as the British Medical Journal gives the number of deaths from sickness as 27,185 , while the translator of the Japanese Director-General's paper gives that number as the number of cases of infectious disease. It must be remembered also that 39,635 Russian "missing" were allocated in the available statistics at the same rate of mortality as obtained in the Russian hospitals, although it is not definitely known what became of them.

And now to speak of previous sanitary corps.

The Northern States military authorities in the American Civil War attempted the reduction of the sickness inefficiency and mortality by organizing a special sanitary staff, but without conspicuous success. The Japanese in the Russo-Japanese conflict had a sanitary corps which obtained strikingly successful results, as you have seen, the percentage of sickness being actually less than in time of peace. I have no knowledge of the Russian sanitary organization, but Dr. Schaefer in "La Revue Militaire des Armées Étrangères" says:- "By adopting measures of hygiene suitable to the climate, and providing for feeding the men by means of wheeled kitchens, the number of Russian sick was less than in time of peace." I gather from this that there was some sanitary corps.

The sanitary corps of the Territorial Force differs, however, from all previous corps, inso- much as it is the first manned by sanitary specialists. Much excellent sanitary work has been done by the British Royal Army Medical Corps, many members of which hold a diploma in public health, but the sanitary duties have been supplementary to other work, and not the primary object of the corps' existence. The Sanitary Corps of the Royal Army Medical Corps, Territorial Force, to give it its full designation, has a peace establishment of 105 of all ranks-viz., one major, two captains, two subalterns, and roo of other ranks.

The war establishment, according to information supplied to me from the War Office, is fourteen divisional sanitary officers in active appointments, and six lieutenant-colonels, forty majors and sixty captains, whose services are available on mobilization. Being a member of the corps on its war establishment, it is scarcely necessary to say I am a friendly critic, and only point out what appear to me to be defects in the hope that they may be remedied, and recommend changes with a desire for efficiency. As a junior öfficer I make my remarks with considerable diffidence, and hope they may not be considered presumptuous.

Beginning with the War Office, it is necessary that each sanitary officer should have a properly defined position. $\mathrm{He}$ has none at present. He may be a major or a captain à la suite, which term appears to be a polite variation on the term "supernumerary," but no one has been able to tell me in what relation he stands 
to the combatant officers, the officers of the Royal Army Medical Corps of the Regular Army, or even the superior officers of his own branch of the service.

The officer should be provided with a uniform. All who have any knowledge of the private soldier are aware of the scant respect he pays to anyone not in uniform. This uniform should be issued at once, for there would be so much to do in the event of mobilization, and so little time to do it in, that it is not likely that time would be found for the issue of uniforms.

The uniform is also necessary for the protection of its wearer, who would not have many moments to live if captured out of uniform by an enemy when engaged in his duties. It would not be altogether useless in time of peace if the owner went into camp for training. A question of mine on the subject addressed to the Secretary of State for War was replied to as follows :-

"- I I am directed to inform you that in the case of officers of the Royal Army Medical Corps (Territorial Force) whose services are available only on mobilization, the provision of uniform (service dress) before mobilization orders are issued, though desirable, is left to the option of each individual officer. No outfit grant would be issued until mobilization is ordered."

This may be paraphrased as follows:-The officer is at liberty to provide his uniform at his own expense, but will be paid for it if mobilization is ordered. (Query-Would this be retrospective ?)

Each officer should be attached to a particular unit, and its headquarters should be his, and he should know the extent of the country in which he might be called upon to act upon mobilization. The reason will be shown later on.

The officers attached to each unit should have a squad of men detailed for instruction in camp sanitary work. The Corps as at present constituted has more officers than men. Even if the men trained by them were moved on with the unit in case of mobilization, the officers in charge of the next camp would benefit by their efficiency, while the next incoming regiments would bring other trained men to take their place.

Now I will point out what I consider should be the duties of commissioned officers in time of peace.

The officer should make himself thoroughly acquainted with the country in which he might be called upon to act, not confining himself to the district for which he is medical officer of health. He should know the exact situation of every watermain, public sewer, hospital, and building suitable for a temporary hospital. These should be marked on a map supplied to him for that purpose. The map should be kept up to date and duplicated, and the duplicate deposited at the local headquarters. The officer should also have at least a general idea of the geology of his district, for the nature of the subsoil is of the greatest importance when considering the choice of a camp, temporary or permanent. The officer should go into camp at least once with the unit to which he is attached, and should assist in choosing, or at any rate in laying out, the camp for the annual training. The knowledge of the officer is assumed to be guaranteed by his medical and public health qualifications, and the experience gained previously and subsequently to taking them, and the fact that the officer is in the active practise of his profession is taken to mean that he is fully trained at all times and able to take duty in the field, and that it is therefore unnecessary for him to go into camp in time of peace. I strongly dissent from this assumption. It may be unnecessary in the case of those who have served in the Regular Army or the late Volunteer Force, but there are many others, competent in all other respects, who are quite ignorant of the conditions of camp life. One of these men placed in charge of a camp would be in the position of a learner for some little time, and although he would doubtless soon acquire the small amount of knowledge he lacked, the fact that he displayed ignorance at the outset of his active service would tend to diminish his authority and the respect in which he was held.

Another and very important duty which should not be neglected is the giving of lectures to officers and men. It is more important to give them to the former than the latter. The advice of the sanitary officer must be given to the commanding officer, who in turn gives orders to his officers, who transmit them to the non-commissioned officers, who see that the men carry them out. It is therefore highly desirable that the officers should know the principles on which the advice is based. If lectures are given in camp, all may be compelled to attend, which is not always the case when they are given in a drill-hall or similar building.

Lectures are a necessity, for the sanitary 
education of the soldier must be in time of peace. It is to be remembered that even if the knowledge instilled should not be required in war, it is useful in civil life, and every man who acquires a knowledge of the main principles of sanitation becomes a sanitary missionary among the civil part of the community. The scope of the lectures should include the selection of the camping grounds (mainly for the benefit of the officers), water supply, the destruction of flies, the disposal of refuse, and general sanitation. Other subjects might be usefully added, such as food supply and the prevention of infectious disease ; but the prevention of footsoreness, first aid, personal hygiene and all that appertains to it may be considered as in the province of the other branch of the Royal Army Medical Corps, Territorial Force.

The usefulness of the sanitary officer in case of mobilization will largely depend on his status. He will be of little use unless some change such as has been indicated is made in it, and he is given a properly defined position. I make no excuse for repeating myself to some extent on this point.

On mobilization an official notice, which is always kept in readiness, will be sent to each member of the force by post or otherwise, and the duty of the sanitary officer will be to report himself at the local headquarters as soon after as practicable. Presumably he will then be placed in charge of the sanitary arrangements of the camp, if there should be one; but if not, he will be called upon to assist in laying one out. The choice of the site of the camp will be principally governed by military considerations, but it is conceivable that occasions might occur on which it would be necessary for the officer to give an opinion as to which of two or more sites was the better from a sanitary point of view. It would be then that the knowledge of the district acquired in time of peace would prove of service, but in the absence of such knowledge the assistance of a local medical officer of health or inspector of nuisances might prove invaluable. When the site of the camp has been selected, it will be the duty of the officer to advise as to the positions of the various quarters. This has to be carefully thought out. It would not do to construct latrines so that the prevailing wind brought down myriads of flies to the kitchens, as in the American Philippine Campaign; nor " to pitch the hospital for wounded on the lee side of a hill, getting the full benefit in torrid heat of the flies and smells from a slaughter-house on the weather side," as occurred "after one of the worst actions in Natal" during the late South African War. (Viscount Midleton, when Mr. St. John Brodrick, in the Times.) It is difficult to think that such mistakes would have been made if thought had been taken or the advice of the medical officer followed.

In the Russo-Japanese War, members of the Sanitary Corps of the Japanese Army Medical Corps moved in advance of the troops. They inspected the wells, tested the water, and if it proved to be of a satisfactory nature, placed a sentry over it to prevent its being fouled or poisoned. Provision was made for the boiling and filtration of water; unwholesome places were disinfected and refuse burned; houses in the villages were made sanitary, or if this was impossible, burned; baths and latrines were constructed. Notices were placed at the entrances of villages showing the number of houses, the quartering capacity, the wholesomeness or otherwise of the wells, and the existence or non-existence of infectious disease.

Some other preventive measures which were taken were, perhaps, not within the scope of the duty of the Sanitary Corps-e.g., the issuing of portable filters and creasote pills (called Seiro-gan, or "Invasion of Russia" pills). Although this work was necessary in Manchuria, it is to be hoped that much of it would not be required in the event of a campaign in the British Isles, to which the service of the Territorial Force is confined.

Before concluding, I may remark that it has always appeared to me that the services of inspectors of nuisances should be utilised in connection with the Territorial Force. Most of them, especially those of the larger rural districts, would make most excellent guides, knowing as they do the short-cuts and footpaths. It would, of course, be necessary to give them uniforms for reasons already given. Many of them would make admirable noncommissioned officers in the sanitary corps.

The Prevention of Consumption.-The Tottenham Council, on the application of Dr. Butler-Hogan, its medical officer of health, has granted the free use of the Council Chamber on Wednesday, December 15 th, for the purpose of a lecture on "The Prevention of Consumption," by R. W. Philip, Esq., M.D., F.R.C.P., of the Royal Victoria Consumption Hospital, Edinburgh. As the seating accommodation is limited, early application should be made to the M.O.H., Town Hall, Tottenham, by medical officers and others wishing to be present on the occasion. 